\section{The Results of Public Accommodation Establishments in Northern Hungarian Region, with Special Regard to Heves County}

\author{
Szabó Róbert \\ Eszterházy Károly College, Faculty of Economics and Social \\ Sciences, \\ Institute of Economic Sciences, Department of Tourism \\ szabo.robert@ektf.hu
}

\section{SUMMARY}

The study shows the results of public accommodation establishments (especially in Heves County) in the period of 20002009 in the context of basic touristic statistical indicators like the number of public accommodation establishments, capacity, arrivals, bednights, average length of stay, revenue (structure of revenue). According the study, we can conclude that on the basis of the capacity, number of guests and number of bednights of public accommodation establisments, Heves County (as compared to other counties of the region) played a pivotal role in the tourism of Northern Hungary in the studied period.

Keywords: touristic results, public accommodation establishments, Northern Hungarian Region, Heves county

\section{INTRODUCTION - THE ECONOMIC ROLE OF TOURISM}

The tourism sector has important economic and social embedding, the sector has complex effects on the national economy's development. It plays partial role in the shaping of market situation of several other national economy sectors (like transportation, telecommunication, trade, financial services, health care, cultural and sport services), while the demand of tourism sector is just indirect in case of the products or services of other sectors (in agriculture, industry, building industry, environment protection). According to tourism organizations and experts, in the third millennium's first decade the health tourism travels (within the tourism travels) shows the most dynamic development.

The economic impacts of tourism can be analyzed from the sending- and the hosting area's correlation. In both cases it is an important condition to have regular and reliable data (statistical database and standard interviews) from the field of tourism, for the researchers to define the real impacts of tourism.

The following factors play an important role in the variations of economic impacts of tourism:

- Economic level of the sending- and hosting area

- Life cycle of the touristic destination

- Touristic capacity of the hosting area

- Quantity and structure of tourist's spending

- Seasonality of tourism

- The use of revenues from tourism (tourism taxes)

- Legal and economic regulations of local tourism (Mundruczó and Stone, 1996)
I have divided the public accommodation estabishments into two different types under my hypotheses and the analysis, such as ,hotel type public accommodation establishments" and ,other type of public accommodation estabishments". The different levelled hotels come in the first group (from 1 to 5 star hotels), including spa, wellness and apartment hotels. To the second group „other" accommodation types were rated like: boarding houses, tourist hostels, youth hostels, bungalows and camp sites.

\section{TOURISTIC ENDOWMENTS ATTRACTION FACTORS OF THE REGION}

The touristic endowments of the Nothern Hungarian region can be called complex and multielemented. This fact is the determinative strength of the region. The most of the attractions has been appreciated during the past some years, appeared expanding contented touristic products, and the awareness of the attractions has been grown. Beside the three World Heritage Attractions (Hollókö and the Aggtelek stalactite cave, the Tokaj-hegyalja historical wine growing area, and Ipolytarnóc prehistorical excavation site), appears four wine growing regions (Mátrai, Bükkaljai, Egri, Tokajhegyaljai). Can be mentioned also the historical towns, and other heritages (fortresses, castles), sacral and historical memorials, national parks, and hills (Mátra, Bükk, Zemplén), thermal baths, and spas, climatic health resorts, newly created theme routes, year by year recurring international and national events. Every attraction contributes to the region's touristic potential in national and in international context too. At the latest development strategic document 4670 pieces of attraction factors were identified in the attraction factor inventory. (RMC, 2006) Table 1.

Can be found some attraction elements, those are ,potential” attractions: exists, holds values, but not used yet, as touristic attractions. Most of them received „local attractions”, or „subregional attractions" mark. The situation is closely the same at the theme routes, these exists only as ,marketing elements", the real product development work still waits, but in long run this would be profitable. Finally can be mentioned, that some attraction elements are missing from the list, those can be inportant in the future, such as extreme sport sites, and monuments used for tourism purposes. (RMC, 
2006).

Table 1

Touristic attraction factors and their scopes in the Northern Hungarian Region (in pieces)

\begin{tabular}{|l|c|c|c|c|}
\hline $\begin{array}{c}\text { Scope of } \\
\text { attraction } \\
\text { factors }\end{array}$ & $\begin{array}{c}\text { Borsod- } \\
\text { Abaúj- } \\
\text { Zemplén } \\
\text { county }\end{array}$ & $\begin{array}{c}\text { Heves } \\
\text { county }\end{array}$ & $\begin{array}{c}\text { Nógrád } \\
\text { county }\end{array}$ & $\begin{array}{c}\text { Northern } \\
\text { Hungarian } \\
\text { Region }\end{array}$ \\
\hline Local & 965 & 459 & 424 & 1839 \\
\hline Subregional & 516 & 387 & 186 & 1089 \\
\hline Regional & 335 & 192 & 150 & 677 \\
\hline National & 358 & 170 & 85 & 613 \\
\hline International & 173 & 219 & 60 & 452 \\
\hline Total & 2338 & 1427 & 905 & 4670 \\
\hline
\end{tabular}

Source: (RMC, 2006) according to RMC database, own design

The type of the attraction factors shown by the Table 2. According the datas of the attraction factor inventory, in the region the natural, and the cultural attraction factors has dominant position.

Table 2

The type of the touristic attraction factors in the Northern Hungarian Region (in pieces)

\begin{tabular}{|l|c|}
\hline \multicolumn{1}{|c|}{$\begin{array}{c}\text { Type of attraction } \\
\text { factors }\end{array}$} & $\begin{array}{c}\text { Northern Hungarian } \\
\text { Region (total) }\end{array}$ \\
\hline Natural & 1104 \\
\hline Cultural and heritage & 2688 \\
\hline Health touristic & 107 \\
\hline Wine and gastronomy & 159 \\
\hline Leisure activity & 484 \\
\hline Other & 128 \\
\hline
\end{tabular}

Source: (RMC, 2006) according to RMC database, own design

Northern Hungary is an attractive destination for those tourists who during their stay would like to enjoy physical and mental relaxation. The region's climatic health resorts, caves, carbon dioxide dry bath (mofetta) are unique in the country, as well as the spa and thermal baths rightly enthralls the followers of wellness lifestyle. These wide range of elements means the main strengths of the region. The supply is enriched by the local existing unique elements, like the Turkish Bath of Eger, the Cave bath at Miskolctaploca, the mofetta at Mátraderecske, the thermal spa at Egerszalók, having special natural surroundings. The touristic supply is further strengthened by the complementary services, like wine-gastronomic, cultural, etc. services, those cannot be found in such a complexity in other parts of the country. The healing effects of thermal waters in the region have long been known, the bathing culture is based on century long traditions, but in the $\mathrm{XX}$. century, during the hydro-carbon researches, new thermal water bases have been revealed. There is strong diversity among the region's thermal water springs, having different mineral combinations, characteristics, so they are able to cure wide range of different diseases. The situation of the region's most important medical and thermal baths has changed a lot in the past few years, the baths renewed, their services expanded. (RMC, 2006)

\section{THE RESULTS OF PUBLIC ACCOMODA TION ESTABLISHMENTS IN THE REGION IN THE MIRROR OF THE NUMBERS}

The quantity and quality of accommodations play determining roles in how effectively the basic supply elements of tourism can be sold. There are several high levelled public accommodation establishments in Heves county, those added to the basic services, also providing wellness services.

In the following I will define (according to specific rules of law) the terminology of public accommodation establishment.

Public accommodation establishment: an establishment built or converted and used for that (accommodation) purpose, if the number of used rooms are over five, and the beds over ten (in case of camp sites, the number of used place units are over five) the establishment of business, on year-round or seasonal basis, continuous daily operations without interruption, providing accommodation and services. The accommodation capacity of less than that indicated in the business of tourism activity must be carried out only in accordance with Government Edict No. 110/1997. (Jun 25th) (KSH, 2010)

We can divided the public accommodation estabishments into two different types, such as „hotel type public accommodation establishments" and „other type of public accommodation estabishments". The different levelled hotels come in the first group (from 1 to 5 star hotels), including spa, wellness and apartment hotels. To the second group „other" accommodation types were rated like: boarding houses, tourist hostels, youth hostels, bungalows and camp sites.

\section{Accommodation statistics in the region}

The accommodation supply (capacity - bed place for tourists) of the counties in the region assigns the region's potential touristic arrivals. The figure below represents public accommodation establishment capacity of the counties in the region. 
Figure 1: Capacity of Public Accommodation Establishments (in bed places)

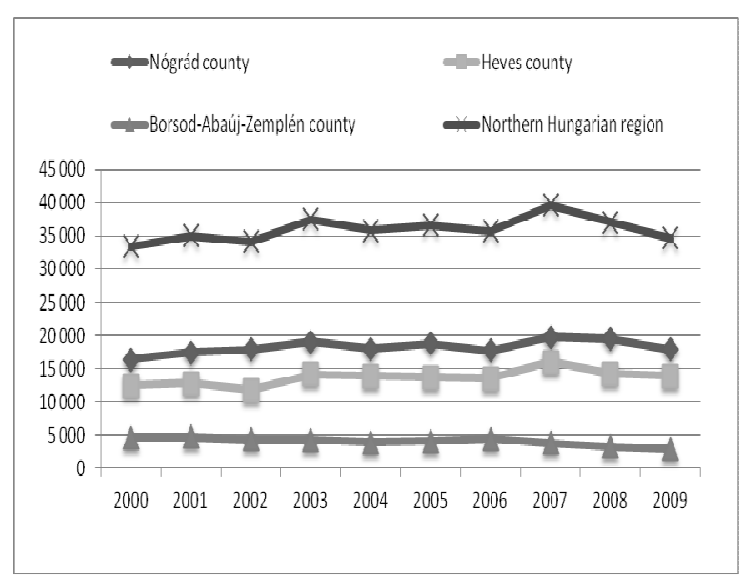

Source: (KSH, 2010) according to KSH database, own design

In Figure 1 it can be seen that the capacity of Borsod-Abaúj-Zempén county is a bit higher than the capactiy of Heves county, but the difference is not so big, as the difference of the spread of the county. At 2009 can be see, that the number of the capacity in Borsod-Abaúj-Zempén county falled down, maybe as the impact of the economic crisis. This fall tendency cannot be obsreve dramatically at the case of Heves, or Nógrád counties.

Across the public accommodation establishment business, analysing the indicators of local tourism, the capacity (number of the bed place for tourists), the tourist arrivals, and the number of tourist night (nights spend by the guests) are significant data. From those data other indicators can be calculated, like room capacity utilization, bed place capacity utilization, revenue capacity utilization, average length of stay, average revenue per guest, etc. (Fazekas et al., 2005)

Figure 2: Arrivals at Public Accommodation Establishments - number of tourist arrivals (in persons)

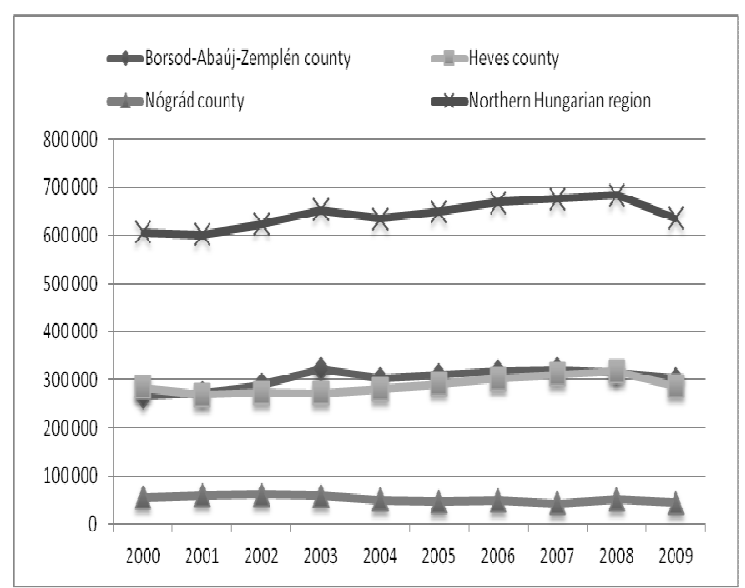

Source: (KSH, 2010) according to KSH database, own design

From the Figure 2 and 3 can be see, that before the crisis the number of the guests, and the number of the bednights were slightly grow, but at the beginning of the crisis happened setback. According to Figure 2 and 3 we can find out that although Borsod-Abaúj-Zemplén county has a bit better position than Heves County in bed place capacity, but in the number of tourist arrivals and in the number of bednights, their performance were nearly the same during the observed period. At figure 3 (unfortunately I found datas for 2009 and 2010 only about the whole region) in 2009 can see a dramatically throw-back in the number of bednights, but in 2010 again can be see a little growing tendency, that can be optimistic, out of the crisis.

Figure 3: Arrivals at Public Accommodation Establishments - number of bednights (in nights)

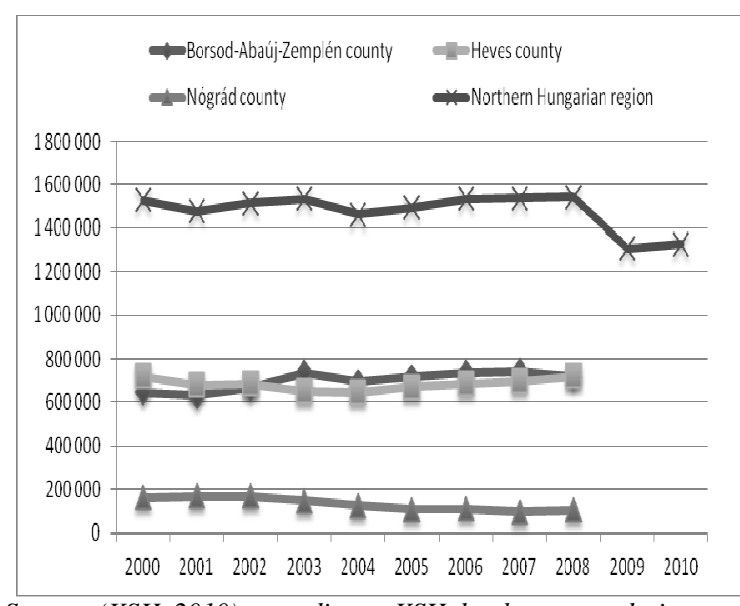

Source: (KSH, 2010) according to KSH database, own design

Figure 4: Average length of stay at Public Accommodation Establishments (in nights)

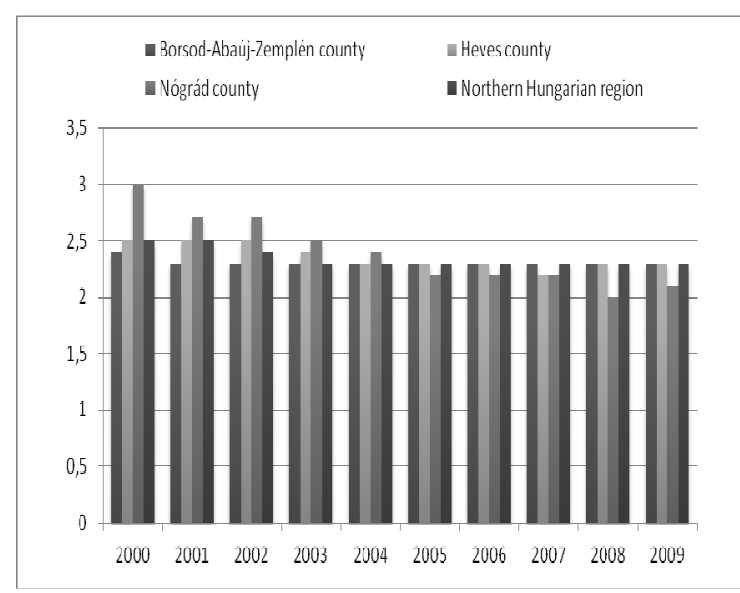

Source: (KSH, 2010) according to KSH database, own design

The average stay indicator can be calculated easily, we simply have to divide the number of total tourist nights by the number of total tourist arrivals. The average length of stay is one of the indicator of success of the destination, which shows how long the guests would stay at the destination (and so, how long they will spend money there). At Figure 4 it can be seen that the average length of stay at the region's public accommodation establishments changes between 2,2 to 2,4 bednights, which is true for the average of the region, too. According the datas, there 
wasn't setback in the crisis peridod, the average length of stay was successfully hold.

\section{The types of public accommodation establishments in Heves County}

Figure 5 shows below the number of units of different public accommodation establishments and how it changed between the period of 2000 and 2008. It can be mentioned that in the unit number of the hotel type accommodations there were not any significant changes. In 2004 there was a little increase, but to 2007 it fell back to the level of 2004. Dramatic decrease happened in case of the boarding houses from 2003, and they could not reach that level during the analysed period again.

Figure 5: Number of the different Public Accommodation Establishments in Heves County (in units)

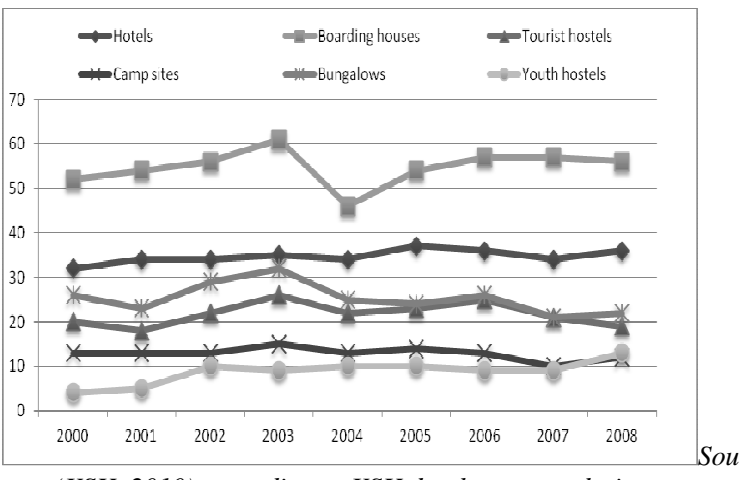

rce: $(K S H, 2010)$ according to KSH database, own design

The structure of the revenues of public accommodation establishments in Heves County

The number of public accommodation establishment units influences the created revenues in the county. Figure 6 represents the revenues of the county's public accommodation establishment, and also shows the structure of revenue compostitions. According to Figure 6 it can be mentioned that little more than $50 \%$ of the revenues came from the room prices, an important amount came from the catering services, but the „other" revenue division takes half of the revenues average from catering.

Figure 6: Structure of revenues at Public accommodation Establishments in Heves County (in thousand HUF)

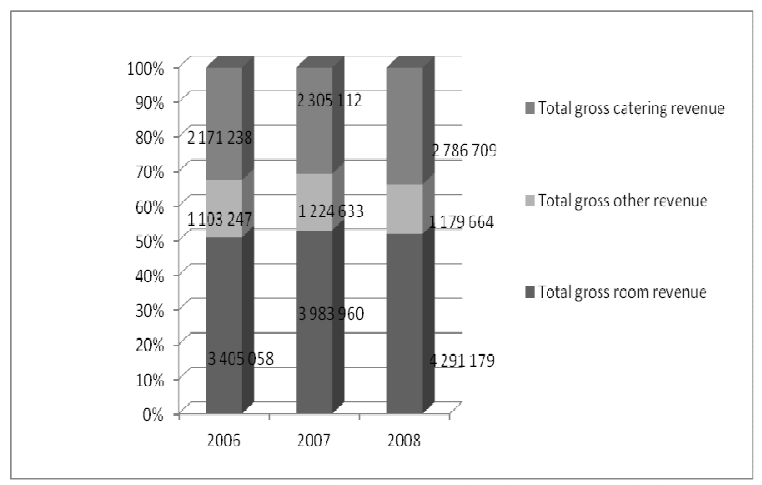

Source: (KSH, 2010) according to KSH database, own design

\section{CONCLUSION}

According to the above demonstrated results, we can conclude that, despite it's smaller area, and lesser touristic attractions, on the basis of the capacity, number of guests and number of bednights of public accommodation establisments, Heves County (as compared to other counties of the region) played a pivotal role in the tourism of Northern Hungary in the studied period.

\section{REFERENCES}

Fazekas G.-Földi Zs.-Szabó Z.-Török L.(2005): Turizmus és vendéglátó ismeretek. Szókratész Külgazdasági Akadémia, Budapest

Jandala Cs. (1992): A turizmus közgazdasági elemzésének módszerei. KIT (Kereskedelmi és Idegenforgalmi Továbbképző Kft.), Budapest

KSH (2010): stADAT-táblák, Idősoros éves adatok, Területi statisztika, http://portal.ksh.hu/portal/page?_pageid=37,599051\&_dad=po rtal\&_schema=PORTAL

Mundruczó Gy. - Stone, G. (1996): Turizmus - elmélet és gyakorlat. Közgazdasági és Jogi Könyvkiadó, Budapest RMC (2006): Észak-Magyarországi Régió Turizmusfejlesztési stratégiája 2007-2013. RMC Regionális Marketing Centrum Kft., Miskolc 